power of the Cairo gas is determined, and where paint, oils, cement, asphalt, \&c., are tested for commercial purposes. Further, the purity of the water supply of Cairo demands constant attention, while the river water and the silt which the Nile carries in suspension during a large portion of the year have to be repeatedly examined. These are matters which must be passed over with a bare mention, though doubtless the management finds the addition of such investigations sufficiently exacting.

More immediately connected with the work of the department appear to be the hydrographic survey of the Nile and river gauging. For the efficient examination of questions connected with this subject a permanent gauging station has been erected at Sarras, thirty-three miles below Wady Halfa, and here are measured in various ways some of the factors that determine the quantity of water in the river. The work is hardly out of the experimental stage at present. A main object is to determine the most appropriate kind of apparatus that will give accurate results with the least expenditure of labour. This section is very interesting, and tables are added showing the volume of water discharged in cubic metres per second, and the mean velocity per second, with other details. The velocity and volume both increase up to the end of August, when, unfortunately, observations were discontinued, though the time of maximum was not reached. A preliminary discussion of the results has shown that the volume of the discharge at Khartoum, when the Atbara was not contributing, was greater than that at Aswan by amounts which could not be explained by loss from evaporation or from use in irrigation. The cause of the loss is not yet decisively explained, though Captain Lyons makes a plausible suggestion.

Another feature of the report is the description of the Helwan Observatory, which seems to be very fairly equipped with magnetic, meteorological, and seismological instruments. Of the astronomical portion, we learn that the 30 -inch reflector presented to the Egyptian Government by Mr. R. H. Reynolds, of Birmingham, is in course of erection, and that all the heavy castings are in position. Some of the mechanism has been returned to England for alteration, and the completion of the erection awaits the return of these essential fittings.

Of the geodetic work properly so-called, details are given of the second order triangulation with all necessary fulness. The standard of accuracy attained is not quite that of the highest order, but sufficient for the object for which the measurement was undertaken, namely, the control of the map sheets used in the revenue survey of the country. It is now possible to base a map of Egypt on a connected triangulation from Damietta to Wady Halfa, an extent of nine degrees. Of even greater importance, however, is the triangulation, which it is to be hoped will be ultimately carried out, whereby Egypt will contribute to the measurement of the arc of meridian, which in its entirety will extend from the Cape of Good Hope to the North Cape, along the thirtieth parallel of east longitude. For several years Sir David Gill has been engaged in carrying this chain of triangulation northward, and the prospect of completing a measured arc of some $100^{\circ}$ of latitude cannot but be of profound interest to the astronomer, the geologist, and the physicist. Captain Lyons, however, is fully aware that the value of such a work consists very greatly in the maintenance of the same standard of accuracy throughout. The most difficult problem of geodesy, he tells us, is to pass from a particular platinum and iridium bar, on which the length of the metre is defined, to the length of a base line over a more or

$$
\text { NO, I } 94 \text { I, VOL. } 75]
$$

less rough land surface with as great an accuracy as possible. Viewed in this light, the most interesting portion of the report consists in the description of the method of the comparison of the bars and Jaederin wires used in Egypt. The accuracy seems quite satisfactory.

W. E. P.

\section{INTERNATIONAL FISHERY}

\section{INVESTIGATIONS.}

THE results of the first two or three years of active investigation in connection with the general scheme of fishery research, which is being carried out in the seas around north Europe under the auspices of the International Council for the Exploration of the Sea, are now being rapidly published in a series of reports issued in part by the Bureau of the International Council and in part by the authorities of the different countries participating in the international scheme. As the outcome of the work is being thus gradually brought to light, the comprehensive character of the programme becomes increasingly obvious. The remarkable scientific interest of the results obtained from what is probably the greatest and most serious attempt yet made to carry out a scientific investigation by means of international cooperation is placed beyond dispute, nor can it be doubted that the eventual practical benefit of these researches will be of even more importance and of much direct value to the fishing industry.

The first report under review contains detailed accounts of some of the work carried out in 1902 and I903, whilst in the Marine Biological Journal Mr. James Johnstone, of the Liverpool University Fisheries Laboratory, gives a useful résumé of the results published up to the summer of 1906. The remaining reports deal for the most part with more recent publications.

As must be by this time well known, three main lines of research are being developed in the international scheme, the hydrographical, the biological, and the statistical. The hydrographical investigations record and endeavour to explain the constantly changing physical conditions under which fishes pass their lives; the biological investigations aim at a complete account of the life-history of the more important food-fishes, as well as a detailed knowledge of the various smaller marine creatures which serve as the food of fishes; the statistical investigations deal primarily with the variations in the actual quantities of fish removed from the different fishing-grounds and brought to market, and at the same time yield considerable material which is capable of supplementing and amplifying the knowledge of the history of the fishes obtained from the biological observations. Although the three branches of the investigation are for practical reasons carried out more or less independently, the ultimate success of the work depends upon the judicious combination of the knowledge gained from each, and its application to particular problems of the fishing industry.

A striking example of the success of such a combin-

1 Reports of the British Delegates attending the Meetings of the International Council for the Exploration of the Sea in 1903,1904 and 1905 , and Reports and Correspondence relating Thereto. Vol. ii., General Report of the International Council for rgonent international pour l'Exoloration de la Mer. Rapports et Procèspermanent international pour l'Exoloration de la Mer. Rapports et
Verbaux, vol. iii. (London: Printed for H.M. Stationery Office.)

erbaux, vol. iii. (London: Printed for H.M. Stationery Office.) Conseil permanent international pour l'Expluration de la Mer. Rapports
et Procès-Verbaux vols. v, and vi.; Bulletin trimestriel des Résultats et Procès-Verbaux, vols. v. and vi.; Bulletin trimestriel des Résultats acquis pendant les Croisières périodiques et dans les Périodes intermédiaires, Année r 1905-1906, No. 3, Janvier-Mars, T906; Bulletin statistique des
Pêches maritimes des Pays du Nord de I'Europe, vol. i.. pour les Années r 903 et r 1904 . Journal of the Marine Biological Association of the United Kingdom,
vol. vii., No. 5. 
ation is contained in Dr. Johansen's paper on the plaice fishery of the Kattegat, and the means whereby it may be improved (Rapports et Procès-Verbaux, vol. v., p. 45). From a study of statistical data it is shown that although the intensity of fishing for plaice in the Kattegat, in consequence both of an increase in the number of boats and of improvements in the fishing gear, has increased very greatly since $188_{5}$, the actual weight of plaice landed has remained practically stationary from that year until 1904, the year for which the last statistics are available. It is only a rise of about 200 per cent. in the price of plaice that has enabled so many boats to continue profitable fishing; but although the total weight of fish has neither increased nor decreased during the period mentioned, there has been a marked decrease in the average weight per fish, so that the plaice harvest is now composed of a much larger number of smaller fishes than was formerly the case. Johansen, following out an idea previously developed by Petersen, shows that at the present time by far the greater number of plaice are captured before they have attained the size at which their value per unit of weight is greatest.

Biological investigations carried out in the Kattegat have shown that there are important differences between the plaice populations in the northern and in the southern parts of the area. In the northern Kattegat the fish are large and well grown, and attain sexual maturity at a later age and larger size than those in the southern Kattegat. This change in the character of the fish population is correlated with the changes in the hydrographical conditions which take place as the Baltic is approached. The plaice supply of the southern Kattegat consists chiefly of small fish already sexually mature, that of the northern Kattegat of larger and more valuable fish which have not yet attained maturity.

The principal nurseries for young plaice near the Danish coast have been investigated, and the fact that the rate of growth of the fishes on some of these nurseries, as determined both by marking experiments and by examination of otoliths, is abnormally low suggests that these particular grounds are overcrowded with young fish. This condition is not, however, found in either the Kattegat or Skagerak, and in the southern Kattegat the rate of growth during the first two or three years of the life of the plaice is as rapid as in the northern part, although in later years it becomes much less rapid. The experiments with marked fishes which have been carried out on plaice in the Kattegat have shown that far more than 50 per cent. of the plaice are re-captured each year, thus indicating a very high intensity of fishing.

After a careful review of the evidence gathered from all the different lines of research, Johansen comes to the conclusion that the enforcement of a minimum size-limit for Kattegat plaice of $30 \mathrm{~cm}$. (12 inches) would result in an increase in the value of the fishery amounting to from 5o per cent. to roo per cent., although the exact figure can only be determined by experiment. Further, since in certain parts of the Kattegat only insignificant numbers of small plaice are found, but these grow rapidly, he thinks that the transplantation of large numbers of small fish from more crowded nursery grounds to such places would be worth a trial.

A study of Johansen's paper can hardly fail to leave the impression that a great advance has been made towards the solution of the more important problems connected with the plaice fishery of the Kattegat, and that promising practical schemes, based upon a rational understanding of the questions NO. I 94 I, VOL. 75$]$ involved, are already in prospect for the improvement of that fishery. The Kattegat is a somewhat circumscribed sea-area of moderate dimensions, and it will be scarcely surprising if the end to which all scientific fishery investigations are directed is first achieved there; but the reports before us show that work upon quite similar lines is being rapidly done on the plaice fisheries of the larger region, which may be described as the middle and southern North Sea. The summary of the investigations of the German, Dutch, and English naturalists, which is contained in the report of Dr. Garstang, the convener of Committee B ("Reports of British Delegates," vol. ii., p. I9I), in that of Dr. Redeke (ibid., p. 265), and in the various statistical papers by Henking (ibid., p. 127), Hoek (ibid., p. 300), and Kyle (ibid., p. 363 , and especially Bulletin statistique, vol. i.), foreshadot as complete and satisfactory a solution of the problems in this area as has been, one might almost say, already achieved in the Kattegat.

In the larger area the marked-fish experiments have already yielded much valuable information, and it ought not to be long before a fairly complete account is available of the normal migrations of the plaice. The transplantation of small plaice from the crowded nursery grounds along the coast to the shallow waters of the Dogger Bank, in the middle of the North Sea, has been attended with a high measure of success, the growth of the transplanted fish having been several times greater on the Dogger than on the inshore grounds. An experiment in transplantation upon a very much larger scale is the next step which appears to be called for.

The plaice, however, is only one amongst the many fishes which have received attention. Much interesting work has been done on the haddock and on the cod, although most of the reports so far published are of a preliminary character only (Hjort and Petersen, "Reports of British Delegates," vol. ii., p. I53).

The herring, too, is receiving attention, and the statistical data brought together by Kyle (Bulletin statistique, vol. i., p. 228), with the accompanying charts, give a graphic picture of the movements of the herring fleets, and therefore, presumably, of the fish themselves. The attempt already begun to correlate these movements with changes in the hydrographical conditions will almost certainly yield valuable guidance to the herring fishermen, and ought to enable them to avoid much fruitless shooting of their nets.

A striking piece of work is Dr. Johs. Schmidt's contribution to our knowledge of the life-history of the common eel (Rap. et Proc.-Verb., vol. v., p. 137). Grassi and Calandruccio had already followed, from specimens taken in the Straits of Messina, the different stages in the metamorphosis of the eel larva from Leptocephalus brevirostris to the young elver, and they had suspected that the natural home of the Leptocephali was in deep water, their occurrence in the Straits of Messina being due to the peculiar nature of the currents and the upwelling of water from the deeps. Schmidt's researches, carried out on the Danish investigation steamer Thor, to some extent confirm this view, rendering it at the same time more precise, and the spawning grounds of the European eel and the home of the eel larvæ are now for the first time made clear. It is along the edge of the continental slope, to the west of the British Isles, that the young eel larvæ (Leptocephalus brevirostris) are found in large numbers, in regions where the depth of the water is about 500 fathoms and the bottom temperature is at least as high as $7^{\circ} \mathrm{C}$. The larvæ themselves are not, however, near the bottom, 
but occur chiefly in the upper and middle water layers, being found during the daytime in greatest numbers about 50 fathoms below the surface. The inference is obvious that the female eels spawn on the bottom in the same or a neighbouring area to that in which the larvæ are taken. The highest point of larval development seems to occur in June; the Leptocephalus has then ceased to feed, and the next stage of its existence is a long, retrogressive metamorphosis, during which it decreases in size in all dimensions, and gradually takes on the slender eellike form. During the latter part of the metamorphosis the larvæ, or elvers as they may now be called, become very active, and commence their great migration towards the coast and the fresh waters in which they feed and grow. The whole process of metamorphosis occupies about a year, and during this time the young eels take no food at all.

Schmidt has obtained information from localities all along the west coast of Europe, from Spain to Norway, as to the time of year when the young elvers first appear in the rivers, and the interesting fact comes out that the time of occurrence of the elvers on the different coasts depends, in the first place, on the distance from the deep water in the Atlantic where the eels spawn. On the coasts directly washed by the ocean the ascent into fresh water begins between September and December, or even in January or February, according to the distance from the deep water, whilst on the coast of Denmark and in the inner Danish waters the elvers do not arrive until April and May.

The whole story of the life of the common eel, as now made clear by these investigations, is one of the most fascinating which it has fallen to the lot of any naturalist to unravel. We can picture the great shoal of parent eels, the long journey from the inland waters ended, arriving at their proper spawning places in the deep Atlantic along the whole length of the European coast; the floating eggs gradually developing into transparent, deep-ribbon-shaped Leptocephali; the slow transformation to slender, active elvers; the vast multitude of elvers, foodless, their whole energy concentrated and spent in locomotion only, moving steadily in towards the coast, entering the rivers of Ireland and of France, entrapped in the great funnel of the Severn's mouth, pressing on through the English Channel and into the North Sea, a remnant only, when tribute has been paid to all the rivers by the way, reaching the fresh waters of Denmarls and the Baltic coasts; and, finally, the feeding and growth of the eels all over the European continent in preparation for the return migration to the sea.

There can be little doubt that this new knowledge of the life-history of the eel will lead to results of great practical value to the eel fisheries of Denmark. The fact that one large market for Danish eels is in London makes the question one of practical interest to this country also. In the first place, Schmidt points out that since Denmark and the Baltic depend for their supply of young eels upon the general European stock coming from the Atlantic, any protection of the adult fish in Danish waters is quite uncalled for, since even if all the Danish and Baltic eels were caught, only an insignificant reduction in the number of eel larvæ in the deep waters of the Atlantic would result. In the second place, since the evidence seems to show that the main supply of young eels to the Baltic comes from elvers which have travelled through the English Channel, and not around the north of Scotland, only a remnant of the great shoal of migrating elvers reaches that coast, a view which is confirmed by the fact that in Danish

$$
\text { NO. I } 94 \text { I, VOL. } 75 \text { ] }
$$

rivers no such immense runs of elvers are known as are found in the Severn or in the rivers along the Atlantic sea-board. It would seem that whilst the latter rivers, owing to their geographical position and configuration, receive far more elvers than they are able to support, those of Denmark and the Baltic may have a deficient supply. Schmidt recommends, therefore, that elvers should be taken from the western rivers (elvers caught in large quantities in the Severn are sold at from $x d$. to $2 d$. per pound, and one pound contains about 1500 individuals) and transferred to the Danish rivers and to the Baltic, where they are wanted, and where there is room for them to grow into large eels.

Lack of space precludes us from describing in the same detail as we have done for the plaice and the eel the work which is in progress in connection with the other food-fishes. Heincke's report on the occurrence and distribution of the eggs, larvæ, and various age-groups of the food-fishes in the North Sea (Rapports et Procès-Verbaux, vol. iii.), and the papers by Hjort and others on the life-history of the haddock and cod already referred to, clearly indicate results which may eventually be of even greater interest and importance than those described above.

It seems impossible, after an impartial consideration of the volumes before us, to come to any other conclusion than that the International Fishery Investigations are being conducted with marked energy and enthusiasm by all the countries engaging in them, and that the great conception of an international cooperation of men of science having for its object the acquirement of the knowledge necessary for the rational exploitation of the sea on a scientific basis is in a fair way to justify itself in the eyes of the world.

\section{NOTES.}

ON Monday last the Duke of the Abruzzi delivered to a large audience in the Argentine Theatre at Rome a lecture on his expedition to Ruwenzori, and was awarded the gold medal of the Geographical Society of Italy. The King and Queen of Italy were present with their full Court, and the Diplomatic Corps and chief officers of State also attended. The lecture will be repeated at a special meeting of the Royal Greographical Society to be held at the Queen's Hall, Langham Place, on Saturday, when the King and the Prince of Wales have signified their intention to be present.

WE regret to announce that $\mathrm{Mr}$. Cornelius O'Sullivan, F.R.S., known chiefly by his investigations on scientific aspects of brewing, died on January 8 , in his sixty-sixth year. We regret also to learn of the death of Mr. T. R. Dallmeyer, head of the famous optical firm, and formerly president of the Royal Photographic Society.

Major E. H. Hills, C.M.G., R.E., who has been appointed to inspect and report upon the survey departments now working in the protectorates of British East Africa and Uganda, has just left England for Mombasa. On the completion of the above-mentioned work he will proceed to Colombo to make a similar inspection in Ceylon.

A NEW Government farm, to be devoted wholly to tobacco research, is to be opened, says the Pioneer Mail, in the Rangpur district of Bengal, which is believed to contain perhaps the most important tobacco-growing area in the whole of India, the climate and soil in certain parts of the district being admirably suited to the cultivation of the crop. 